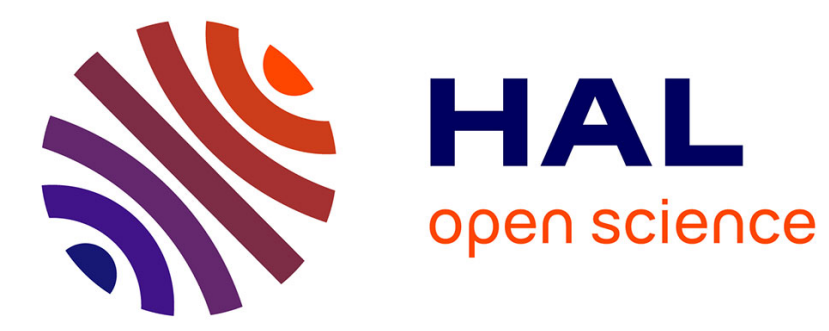

\title{
Hydrocalumite Thin Films for Polyphenol Biosensor Elaboration
}

\author{
A. Soussou, I. Gammoudi, A. Kalboussi, C. Grauby-Heywang, T. \\ Cohen-Bouhacina, Z. M Baccar
}

\section{- To cite this version:}

A. Soussou, I. Gammoudi, A. Kalboussi, C. Grauby-Heywang, T. Cohen-Bouhacina, et al.. Hydrocalumite Thin Films for Polyphenol Biosensor Elaboration. IEEE Transactions on NanoBioscience, 2017, 16 (8), pp.650 - 655. 10.1109/TNB.2017.2736781 . hal-01697381

\section{HAL Id: hal-01697381 \\ https://hal.science/hal-01697381}

Submitted on 31 Jan 2018

HAL is a multi-disciplinary open access archive for the deposit and dissemination of scientific research documents, whether they are published or not. The documents may come from teaching and research institutions in France or abroad, or from public or private research centers.
L'archive ouverte pluridisciplinaire HAL, est destinée au dépôt et à la diffusion de documents scientifiques de niveau recherche, publiés ou non, émanant des établissements d'enseignement et de recherche français ou étrangers, des laboratoires publics ou privés.

\section{다(1)(2)}

Distributed under a Creative Commons Attribution - ShareAlikel 4.0 International 


\title{
Hydrocalumite Thin Films for Polyphenol Biosensor Elaboration
}

\author{
A. Soussou, I. Gammoudi, A. Kalboussi, C. Grauby-Heywang, T. Cohen-Bouhacina, and Z. M. Baccar
}

\begin{abstract}
Hybrid thin films based on Hydrocalumite ( $\mathrm{Ca}_{2} \mathrm{AICl}$ layered double hydroxide $\left.\mathrm{LDH}\right)$ and tyrosinaseenzyme have been used for the elaboration of a high sensitive amperometric biosensor detecting polyphenols extracted from green tea. Structural properties of LDH nanomaterials were characterized by X-ray powder diffraction and Infra-Red spectroscopy, confirming its crystalline phase and chemical composition. $\mathrm{Ca}_{2} \mathrm{AICl}-$ LDHs-thin films were deposited by spin-coating, and studied by atomic force microscopy to obtain information about the surface morphology of this host matrix before and after enzyme's immobilization. Electrochemical study using cyclic voltammetry and chronoamperometry shows good performances of the built-in biosensor with a high sensitivity for polyphenols concentrations ranging from $24 \mathrm{pM}$ to $2.4 \mu \mathrm{M}$ and a limit of detection of $1.2 \mathrm{pM}$.
\end{abstract}

Index Terms-Amperometric biosensor, layered double hydroxide, tyrosinase, hybrid nanomaterial, atomic force microscopy.

\section{INTRODUCTION}

$\mathbf{O}$ VER the past two decades, there has been an exceptionally rapid growth in publications associated to hybrid nanocomposites resulting from the combination of biomolecules and inorganic nanomaterials [1]. The twodimensional (2D) form of these nanomaterials has been used to develop various biosensing devices thanks to their special electronic, optical and mechanical properties [2]. Specifically, among the reported 2D bioinorganic nanomaterials, the association of layered double hydroxides (LDHs) materials and enzymes has emerged as one of the most powerful. In fact, due to their particular structure (consisting of positively charged cation layers with charge balancing anions and water molecules inserted between these layers), inorganic

This work was supported in part by the Tunisian Ministry of Higher Education and Scientific Research and in part by the LOMA. (Corresponding author: A. Soussou.)

A. Soussou is with LOMA, Université de Bordeaux, 33400 Talence, France, also with the Laboratoire de Microélectronique et Instrumentation, Université de Monastir, 5019 Monastir, Tunisia, and also with the Nanobioengineering Group, National Institute for Research and Physicochemical Analysis, 2020 Sidi-Thabet, Tunisia (e-mail: soussou.asma.tt@gmail.com).

I. Gammoudi, C. Grauby-Heywang, and T. Cohen-Bouhacina are with LOMA, Université de Bordeaux, 33400 Talence, France.

A. Kalboussi is with the Laboratoire de Microélectronique et Instrumentation, Université de Monastir, 5019 Monastir, Tunisia.

Z. M. Baccar is with the Nanobioengineering Group, National Institute for Research and Physicochemical Analysis, 2020 Sidi-Thabet, Tunisia.
LDH matrixes have presented specific properties, such as their high ion exchange capacity, their encapsulation ability and their biocompatibility [3]. Many applications have been proposed, based on the immobilization of different enzymes into LDH like urease [4], cholesterol oxidase [5] and lactate dehydrogenase [6].

In this work, tyrosinase enzyme was immobilized onto Hydrocalumite $\left(\mathrm{Ca}_{2} \mathrm{AlCl}-\mathrm{LDH}\right)$ thin films to elaborate a biosensor for the detection of polyphenols extracted from green tea. To our knowledge, it is the first time that Hydrocalumite is used in this context. Tyrosinase catalyzes the oxidation of monophenols and o-diphenols to quinones in the presence of oxygen. The choice of the analyte is justified by the potentially positive impact of polyphenol rich foods on human health, these compounds playing a probable role in the prevention of various diseases [7].

LDH, prepared by the co-precipitation method, was firstly characterized by Fourier Transform InfraRed (FTIR) spectroscopy and X-ray diffraction (XRD) in order to validate its composition and structure. Next, $\mathrm{Ca}_{2} \mathrm{AlCl}-\mathrm{LDH}$ thin films were morphologically optimized using atomic force microscopy (AFM) and then deposited on gold screen-printed electrode (AuSPE) surfaces. Surprisingly, AFM is rarely used in such context, whereas this method is well-adapted. Finally, electrochemical measurements (cyclic voltammetry and chronoamperometry) were used to control the polyphenol detection.

\section{EXPERIMENTAL SECTION}

\section{A. Starting Materials}

$\mathrm{Ca}_{2} \mathrm{AlCl}-\mathrm{LDH}$ (details of synthesis are available in [8]), glutaraldehyde, tyrosinase from mushroom (activity $\geq$ 1000 units $/ \mathrm{mg}), \mathrm{K}_{3} \mathrm{Fe}(\mathrm{CN})_{6}, \mathrm{~K}_{4} \mathrm{Fe}(\mathrm{CN})_{6} \cdot 3 \mathrm{H}_{2} \mathrm{O}$ and phosphate buffer saline PBS (10 mM, $0.137 \mathrm{M} \mathrm{NaCl}, \mathrm{pH}$ 7.4) containing potassium were purchased from Sigma-Aldrich. Polyphenols from green tea (product number 193756) were provided by MP Biomedicals LLC (France). Muscovite mica substrates for AFM experiments were purchased from Electron Microscopy Sciences (USA). AuSPEs for electrochemical studies were purchased from Metrohm (ref. 061208210).

\section{B. Biosensor Elaboration}

The built-in steps of the biosensor are described in Fig. 1. Step 1 consist on the deposition of an ultra thin layer of LDH nanomaterial by spin coating a small volume of 
(1) Spin coating

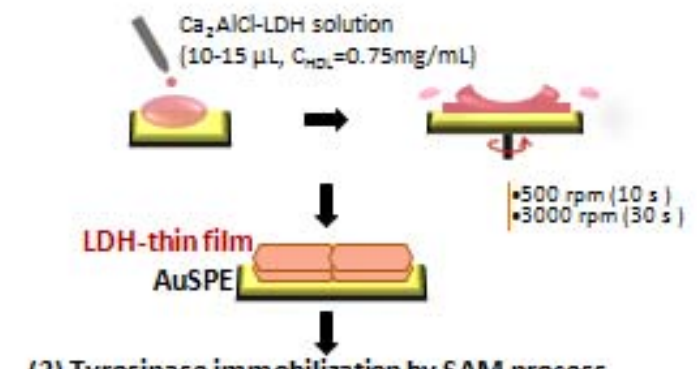

(2) Tyrosinase immobilization by SAM process

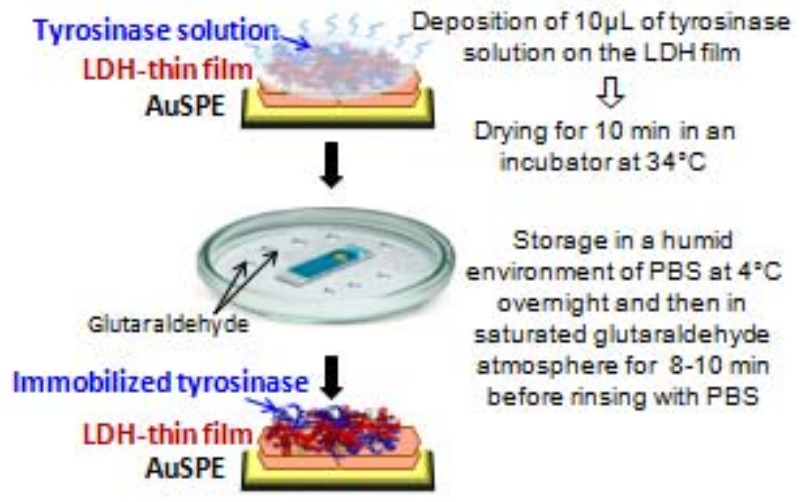

Fig. 1. Scheme of the immobilization of tyrosinase on a LDH film.

$\mathrm{Ca}_{2} \mathrm{AlCl}-\mathrm{LDH}$ colloid $(15-20 \mu \mathrm{L}$, at a concentration of $0.75 \mathrm{mg} / \mathrm{mL}$ ) onto mica or AuSPEs surface. Unbounded LDH particles were removed by rinsing surfaces with milli$\mathrm{Q}$ ultrapure water. Then, tyrosinase $(10 \mu \mathrm{L}$ in buffer, $1.5 \mathrm{mg} \cdot \mathrm{mL}^{-1}$ ) was self assembled (step (2)). After incubation at $37{ }^{\circ} \mathrm{C}$ during $10 \mathrm{~min}$, substrates were overnight-stored in saturated PBS atmosphere at $4{ }^{\circ} \mathrm{C}$. Finally, the enzyme molecules were reticulated in saturated glutaraldehyde atmosphere for 8 minutes and substrates were rinsed carefully with PBS.

\section{Instruments}

XRD measurements were performed on a Panalytical X'Pert Pro diffractometer using $\mathrm{CuK} \alpha$ radiation $(\lambda=1.5406 \AA)$ at $40 \mathrm{kV}, 30 \mathrm{~mA}$.

FTIR spectra of LDHs (in powder) were recorded using a Perkin Elmer spectrophotometer in reflexion mode in the $4000-400 \mathrm{~cm}^{-1}$ range. The final spectra correspond to the average of 10 independent spectra.

AFM study was performed in tapping mode (except for scratching experiments as mentioned in results) with a MultiMode NanoScope II apparatus (AFM imaging) on ambient conditions (in air) using a silicon cantilever (with a nominal spring constant of about $40 \mathrm{~N} \cdot \mathrm{m}^{-1}$ ) and at a scan rate between 0.1 and $0.5 \mathrm{~Hz}$. AFM study was made systematically on three independent samples and different zones were scanned for each one. The surface roughness, which is an important component of surface texture, was obtained using the NanoScope setup after the average of 5 to 10 measurements for each scan.

Cyclic Voltammetry and chronoamperometry measurements were carried out by using an Ivium CompactStat 10800 (Portable Electrochemical and Impedance Analyzer) at room temperature. Gold screen-printed electrodes were used,

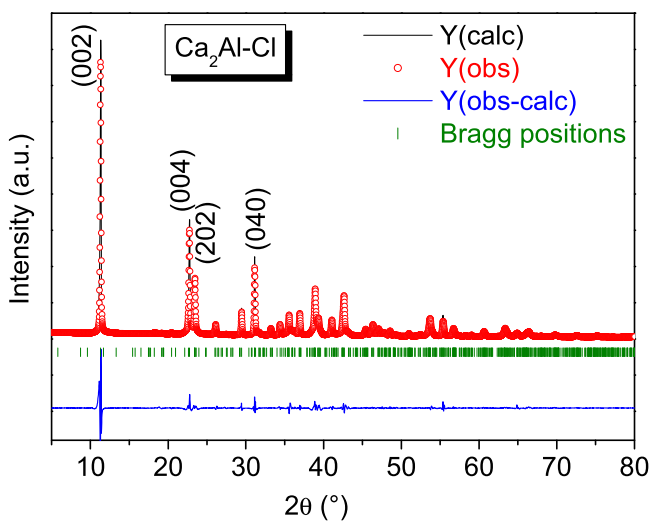

Fig. 2. Experimental XRD pattern (red circles), calculated pattern (solid black line), Bragg reflections (green ticks), and difference pro-files (solid blue line) for $\mathrm{Ca}_{2} \mathrm{Al}(\mathrm{OH})_{6} \mathrm{Cl} \cdot 2 \mathrm{H}_{2} \mathrm{O}$.

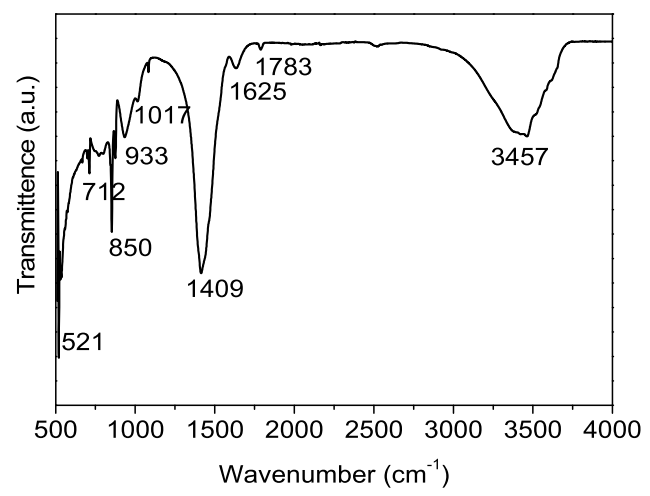

Fig. 3. FTIR (a) spectra of $\mathrm{Ca}_{2} \mathrm{AICl}-\mathrm{LDH}$ (powder).

including a gold working electrode of $4.0 \mathrm{~mm}$ diameter, an auxiliary electrode of carbon and a $\mathrm{Ag} / \mathrm{AgCl}$ electrode as reference electrode. All cyclic voltammetry measurements were carried out at a scanrate of $50 \mathrm{mV} \cdot \mathrm{s}^{-1}$ in PBS solution $(10 \mathrm{mM}, 0.137 \mathrm{M} \mathrm{NaCl}, \mathrm{pH}$ 7.4). For each test, a series of 10 continuous cycles was carried out to ensure the stability and the reversibility of the system. After each serial of measurements, modified electrode were stored in PBS solution at $4^{\circ} \mathrm{C}$.

\section{Results}

\section{A. Structure and Composition of $\mathrm{Ca}_{2} \mathrm{AlCl}-\mathrm{LDH}$}

$\mathrm{Ca}_{2} \mathrm{AlCl}-\mathrm{LDH}$ powder XRD pattern, shown in Fig. 2 (red circles) exhibit the characteristic diffraction peaks $(002,004,202$, and 040) of pure LDH compounds [9]. The Rietveld refinement (Fig. 2) shows that the structure symmetry is $R \overline{3} \mathrm{~m}$ rhombohedral with refined lattice parameters of $\mathrm{a}=\mathrm{b}=0.304 \mathrm{~nm}$ and $\mathrm{c}=2.390 \mathrm{~nm}$. The composition of the Hydrocalumite super cells is $\mathrm{Ca} 2 \mathrm{Al}\left(\mathrm{OH}_{6}{ }_{6} \mathrm{Cl} .2_{\mathrm{H} 2} \mathrm{O}\right.$ with a ratio Ca:Al of 2.

As shown in Fig. 3, FTIR spectrum of $\mathrm{Ca}_{2} \mathrm{AlCl}-\mathrm{LDH}$ exhibits the presence of significant bands: vibrations at $521 \mathrm{~cm}^{-1}, 712 \mathrm{~cm}^{-1}$ and $850 \mathrm{~cm}^{-1}$ can be assigned to metal-oxide ( $\mathrm{Ca}$ and $\mathrm{Al}-\mathrm{O}$ bonds) and metal-hydroxyl vibration modes, respectively. Bands observed at $1409 \mathrm{~cm}^{-1}$ is assigned to the symmetric stretching of carbonate anions, coming from $\mathrm{CO}_{2}$ molecules physisorbed onto the surface [9]. 


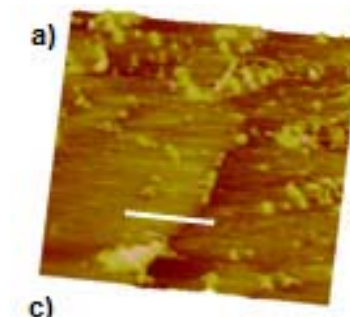

c)
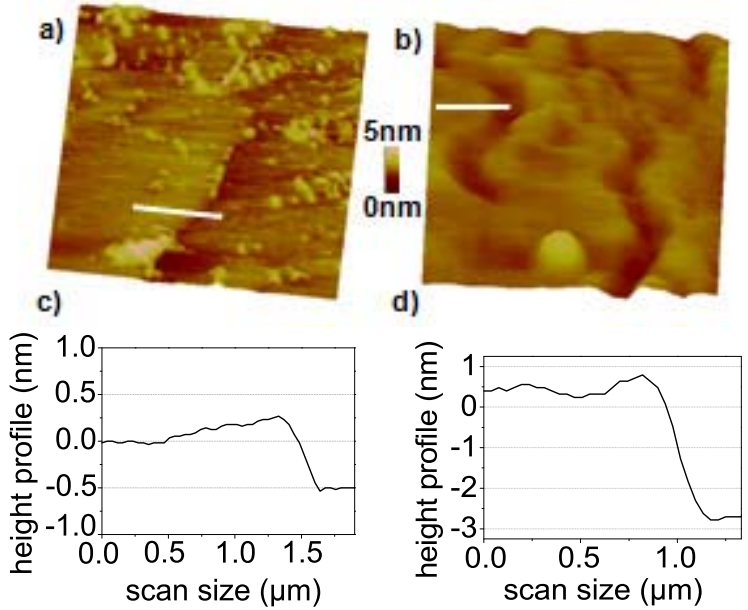

Fig. 4. 3D AFM images $(5 \mu \mathrm{m} \times 5 \mu \mathrm{m})$ in tapping mode of two $\mathrm{Ca}_{2} \mathrm{AICl}-\mathrm{LDH}$ films $\left(\mathrm{C}_{\mathrm{LDH}}=0.75 \mathrm{mg} \cdot \mathrm{mL}^{-1}\right)$ : (a) sample 1 ; (b) sample 2 (a) (c) and (d)height profiles extracted from cross-sections indicated in (a) and (b).
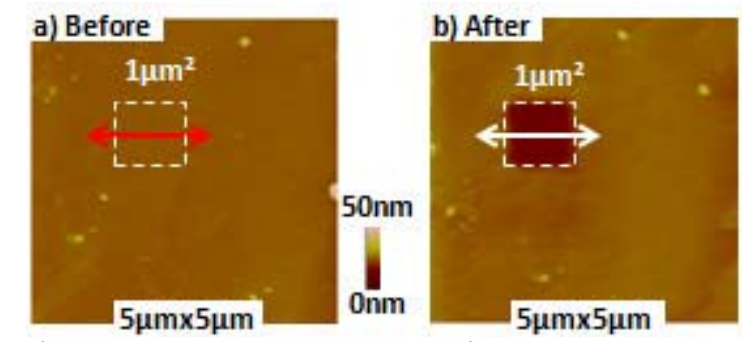

c)

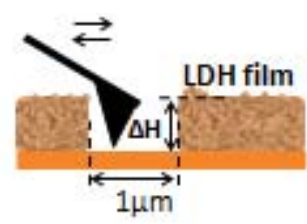

d)

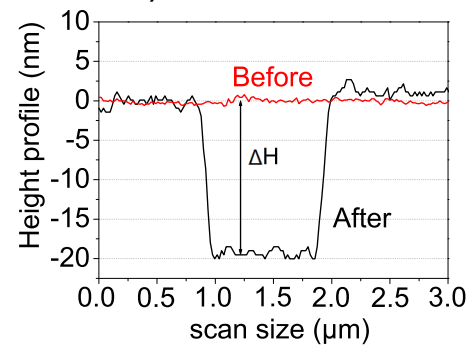

Fig. 5. AFM topographic images $(5 \mu \mathrm{m} \times 5 \mu \mathrm{m})$ of a $\mathrm{Ca}_{2} \mathrm{AICl}-\mathrm{LDH}$ thin film, (a) before scratching; (b) after scratching at the level of the square area; (c) principle of a scratching experiment; (d) section performed along the line shown in (b).

Bands observed at $1625 \mathrm{~cm}^{-1}$ corresponds to the bending mode of water molecules poorly bounded in the interlayer of the LDH powder [9]. At last, at higher wavenumber, the broad band centered at $3457 \mathrm{~cm}^{-1}$ corresponds to the stretching modes of hydroxyl groups, revealing the presence of hydrogen-bonded interlayer water, usually observed around $3300 \mathrm{~cm}^{-1}$ [10].

\section{B. Morphological Characterization of the $\mathrm{Ca}_{2} \mathrm{AlCl}-\mathrm{LDH} / \mathrm{Ty}$ rosinase Thin Films}

Firstly, $\mathrm{Ca}_{2} \mathrm{AlCl}-\mathrm{LDH}$ films were deposited on mica using the spin-coating method (conditions described in Fig. 1). Their surfaces are relatively homogenous (Fig. 4, Fig. 5a and Fig. 6a) containing some dispersed aggregates resulted from the deposition of the suspended LDH-nanoparticles. The average surface roughness is around $8 \mathrm{~nm}$.

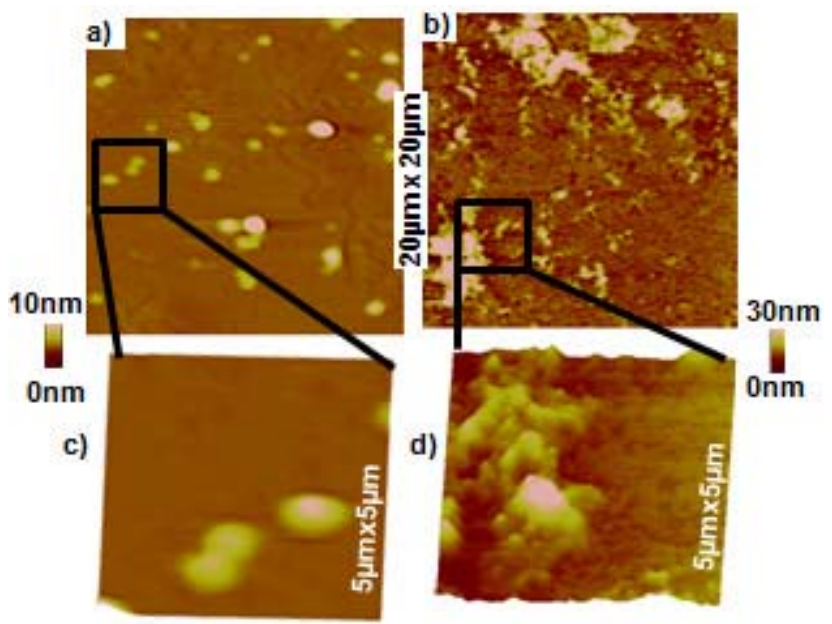

Fig. 6. AFM topographic images $(20 \mu \mathrm{m} \times 20 \mu \mathrm{m})$ of: (a) $\mathrm{Ca}_{2} \mathrm{AICl}-\mathrm{LDH}$ film; (b) $\mathrm{Ca}_{2} \mathrm{AICl}-\mathrm{LDH} /$ tyrosinase film. (c) and (d) the 3D zoom-in (5 $\mu \mathrm{m}$ $5 \mu \mathrm{m}$ ) of the selected areas indicated by squares

on (a) and (b). $C_{\mathrm{LDH}}=0.75 \mathrm{mg} \cdot \mathrm{mL}^{-1}$ and $\mathrm{C}_{\text {tyrosinase }}=1.5 \mathrm{mg} \mathrm{mL}^{-1}$.

Moreover, the $\mathrm{Ca}_{2} \mathrm{AlCl}-\mathrm{LDH}$ films present a multilayers structure like shown by the two LDH samples in Fig. $4 \mathrm{a}$ and $\mathrm{b}$. The thicknesses vary between $0.5 \mathrm{~nm}$ and $10 \mathrm{~nm}$ (Fig. 4c and $d$ ), the minimum value being estimated as the thickness of a single layer.

Scratching experiments were performed on different zones of these samples, in order to determine the total thickness of the LDH thin films (Fig. 5). Such experiments are achieved in the contact mode with a high applied load on the AFM cantilever (around $80 \mathrm{nN}, 10$ times greater than that used for imaging). In this case, when the tip scans a small area (typically, a surface of $1 \mu \mathrm{m} \times 1 \mu \mathrm{m}$, Fig. 5a), it removes locally the LDH layer (Fig. 5b) [26]. Height sections (Fig. 5d) performed between intact and scratched areas estimate a film thickness of about $20 \mathrm{~nm}$, assuming that the lower surface is mica. This was verified using other complementary data (the phase images not shown here).

Fig. 6 shows the AFM topographic images of $\mathrm{Ca}_{2} \mathrm{AlCl}-\mathrm{LDH}$ films deposited on mica before and after the deposition of tyrosinase. After tyrosinase immobilisation (Fig. 6b and d), obvious transformations are observed on the film topography. The aggregates of the tyrosinase film are more massive and cause a change in the image contrast. The roughness and the thickness increase also notably, being estimated (using the scratching method, data not shown) to around 10 and $40 \mathrm{~nm}$, respectively. These data confirm the modification of $\mathrm{Ca}_{2} \mathrm{AlCl}-$ $\mathrm{LDH}$ films, validating the presence of the tyrosinase and the functionnalization procedure. The same protocol deposition conditions were afterwards applied to the AuSPE surface.

\section{Electrochemical Characterization}

Electrochemical properties resulting from the different AuSPE modification steps were first analyzed by cyclic voltammetry $(\mathrm{CV})$ in order to confirm previous results observed by AFM. CV curves shown in Fig. 7 illustrate the presence of two redox peaks at $0.06 \mathrm{~V}$ and $0.18 \mathrm{~V}$ assigned to 


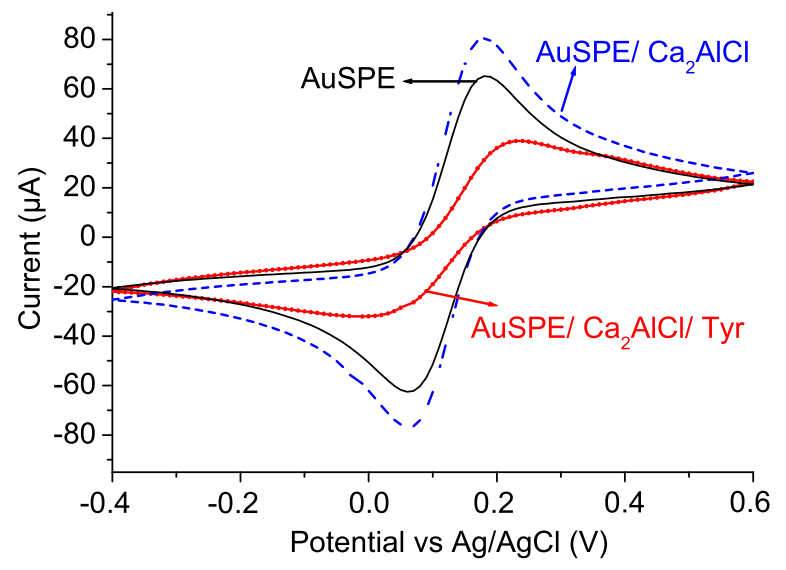

Fig. 7. CV curves of (a) nude AuSPE; (b) AuSPE modified by the deposition of the $\mathrm{Ca}_{2} \mathrm{AlCl}-\mathrm{LDH}$ film; (c)AuSPE modified by the immobilization of tyrosinase on the $\mathrm{Ca}_{2} \mathrm{AICl}-\mathrm{LDH}$ film. Experiments were carried out in PBS containing the $\mathrm{Fe}(\mathrm{II}) / \mathrm{Fe}$ (III) couple $(0.03 \mathrm{mM})$, at room temperature.

the $\mathrm{Fe}(\mathrm{CN})_{6}^{-3 /-4}$ couple [11]. They also show that the presence of the LDH film amplifies the current of the redox peaks, whereas its functionnalization by the enzyme reduces its intensity of the current and modifies the CV shape. These results in agreement with previous work in litterature [12] and [13] confirm the deposition of $\mathrm{Ca}_{2} \mathrm{AlCl}-\mathrm{LDH} /$ tyrosinase hybrid film onto the electrode surface and the well conformation of the immobilized enzyme for polyphenol catalysis.

After this first step, detection of polyphenols was studied. When adding different volumes of polyphenols, the enzymatic reaction [14] between tyrosinase and polyphenols molecules starts: firstly polyphenols are enzymatically oxidized in o-diphenols; secondly, these compounds are oxidized by tyrosinase in o-quinones; at last, o-quinones are electrochemically reduced at the active surface, the all process being schematized by the following equation where Tyr represents tyrosinase:

$$
\text { polyphenol } \stackrel{T y r}{\longrightarrow} \ldots \stackrel{T y r}{\longrightarrow} o-\text { quinone } \stackrel{\text { Red. }}{\longrightarrow} o-\text { diphenol }
$$

Fig. 8 shows the amperometric response of $\mathrm{Ca}_{2} \mathrm{AlCl}-\mathrm{LDH} /$ tyrosinase biosensor to polyphenols at $-0.2 \mathrm{~V}$. This potential value is assigned to the reduction on the electrode surface of o-quinones species generated by tyrosinase, as previously mentioned [14]-[16]. Successive amounts of polyphenols were added in PBS, with final concentrations ranging from 0 to $2000 \mathrm{ng} / \mathrm{mL}$. Each adding was separated by $100 \mathrm{~s}$ or $200 \mathrm{~s}$ respecting the stability of the current. The response of the biosensor was fast (Fig. 8a), since after adding the first volume of polyphenols (at time $=100 \mathrm{~s}$ ), $95 \%$ of the current transition occurs after less than $2 \mathrm{~s}$.

The corresponding calibration curve presented in Fig. 8b gives the absolute value of the current variation $\delta \mathrm{I}=\left|\mathrm{I}_{m}-\mathrm{I}_{0}\right|$ at a potential of $-0.2 \mathrm{~V}$, where $\mathrm{I}_{0}$ and $\mathrm{I}_{m}$ are the currents measured in the absence of polyphenol or in their presence at a given concentration, respectively, versus polyphenol concentration, in logarithmic scale.

The variation of the current intensity seems to increases linearly with polyphenol concentration within the range
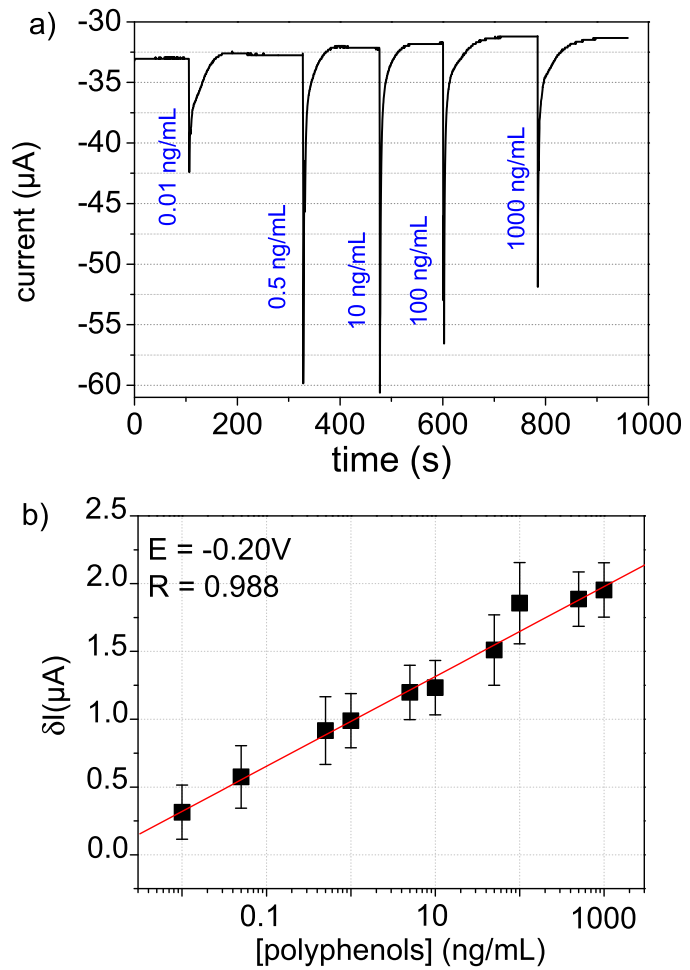

Fig. 8. a) Amperometric response of $\mathrm{Ca}_{2} \mathrm{AICl}-\mathrm{LDH} / \mathrm{tyrosinase}$ biosensor to polyphenols successive additions in the concentration range of $0.01-1000 \mathrm{ng} / \mathrm{mL}$ in PBS. b) Calibration curve corresponding to two additions per decade. The error bars are determined from five measurements.

$0.01-1000 \mathrm{ng} / \mathrm{mL}$ (or $2.410^{-5}-2.4 \mu \mathrm{M}$, taking into account a mean molecular mass of 415 g.mol ${ }^{-1}$ estimated from mean molecular masses of polyphenols present in green tea and their respective amounts [17]), as shown by corresponding calibration curve.

The biosensor is characterized by a high sensitivity of $1.5 \mu \mathrm{A} / \mathrm{ng} \cdot \mathrm{mL}^{-1}$ and a low limit of detection of $0.5 \mathrm{pg} / \mathrm{mL}$ $(1.2 \mathrm{pM})$ estimated using the standard deviation method.

To characterize the kinetic relation between enzyme and substrate we used the graphical method of "Lineweaver Burk" [27]. In our case, the equation is:

$$
\frac{1}{I}=\left(\frac{K_{m}}{I_{\max }}\right)\left(\frac{1}{[\text { polyphenols }]}\right)+\frac{1}{I_{\max }}
$$

At $-0.2 \mathrm{~V}$, the graph giving the inverse of the current as a function of the inverse of the polyphenols concentration is linear (Fig. 9). This curve gives the apparent constant of Michaelis-Menten $\mathrm{K}_{m}$ (estimated here to $21.0 \mu \mathrm{M}$ ) and the maximum value of detected current $\mathrm{I}_{\max }(-26.3 \mu \mathrm{A})$.

The obtained $\mathrm{K}_{m}$ value is compatible with the most reported $\mathrm{K}_{m}$ values in the case of immobilized tyrosinase on biosensor surfaces [14], [28]-[32]. This value indicates that the substrate concentration localized at the active surface of the biosensor is more important than in solution [31], leading to a good sensibility. At last, Fig. 9 suggests that the concentration range where the biosensor response is linear is slightly narrower than the range determined from calibration curve (Fig. 8b), since current saturates at a concentration of $1000 \mathrm{ng} / \mathrm{mL}$. 


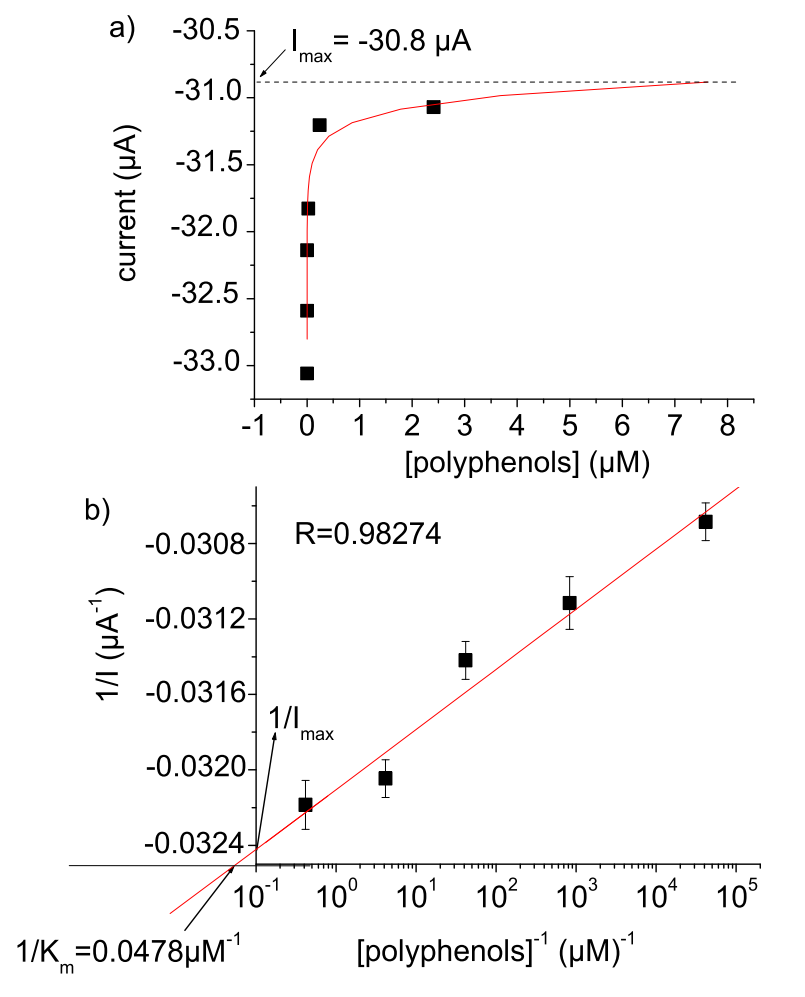

Fig. 9. Lineweaver Burk representation of the degradation reaction of polyphenols by the tyrosinase-enzyme immobilized on the AuSPE $/ \mathrm{Ca}_{2} \mathrm{AlCl}$ system. The error bars are determined from five measurements.

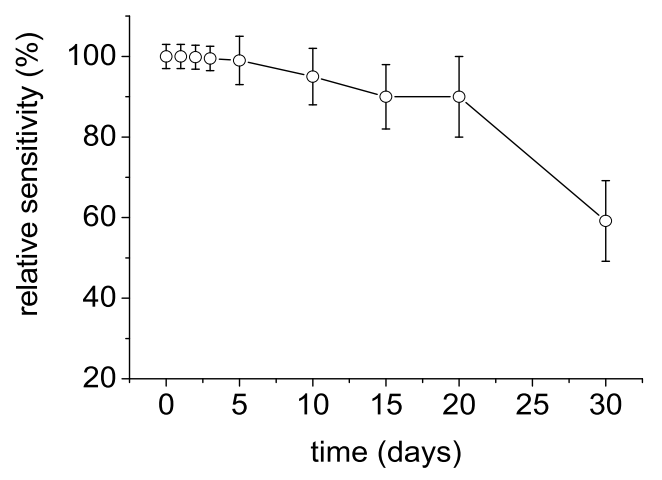

Fig. 10. Study of the lifetime of the AuSPE/Ca $/ \mathrm{AlCl}_{2} /$ tyrosinase biosensor stored in PBS at $4{ }^{\circ} \mathrm{C}$ by following the relative sensitivity (ratio between the measured sensitivity and the initial one as reference) at a potential of $-0.2 \mathrm{~V}$ with time. Error bars are determined from five measurements.

In the end, the stability and the repeatability of the biosensor were studied (Fig. 10).

One test (on the complete concentration range) per day has been done for five consecutive days, and then every 5 days, for 25 to 30 days. Samples were kept in PBS at $4{ }^{\circ} \mathrm{C}$ between each test. Fig. 10 shows that our biosensor is characterized by a high stability, since it retains $90 \%$ and $60 \%$ of its original response after 20 days and one month, respectively.

Finally, our results prove that the biosensor built in this work is highly competitive with previous ones already reported for tyrosinase-based systems. Indeed, our biosensor is characterized by a linear range of $0-2.4 \mu \mathrm{M}$, leading to the conclusion that it is particularly well-adapted to the detection of low concentrations, whereas typical limits of detection and linear ranges usually range from $\mathrm{nM}$ to hundreds of $\mu \mathrm{M}$ in the case of tyrosinase-baed biosensors. In the context of tea polyphenol detection, our maximal concentrations for a linear biosensor response are also coherent with those obtained in tea decoctions, which are around 2-5 $\mu \mathrm{M}$ [14], [15], [18]-[25], [29]-[31], [33]-[37].

\section{CONCLUSION}

This work, benefiting from complementary methods, shows the efficiency of $\mathrm{Ca}_{2} \mathrm{AlCl}-\mathrm{LDH}$ for tyrosinase immobilization, since the immobilized enzyme maintains its activity and functionality. $\mathrm{Ca}_{2} \mathrm{AlCl}-\mathrm{LDH}$ is thus an appropriate host matrix for tyrosinase immobilization on solid supports. The resulting biosensor shows remarkable properties such as high sensitivity within a dynamic concentration range of $[0-2.4 \mu \mathrm{M}]$, a very low limit of detection (LOD) of $1.2 \mathrm{pM}$ and 3 weeks stability.

\section{ACKNOWLEDGMENT}

Authors thank Fabien Moroté, Denise Mondieig and Philippe Négrier (LOMA) and the NSI platform of LOMA (CPER COLA2) for helpful discussions and technical support.

\section{REFERENCES}

[1] C. Liu, J. Shen, K. W. K. Yeung, and S. C. Tjong, "Development and antibacterial performance of novel polylactic acid-graphene oxide-silver nanoparticle hybrid nanocomposite mats prepared by electrospinning," ACS Biomater. Sci. Eng., vol. 3, no. 3, pp. 471-486, 2017.

[2] L. Merhari, Ed., Hybrid Nanocomposites for Nanotechnology. New York, NY, USA: Springer, 2009.

[3] D. Shan, S. Cosnier, and C. Mousty, "Layered double hydroxides: An attractive material for electrochemical biosensor design," Anal. Chem., vol. 75, no. 15, pp. 3872-3879, Aug. 2003.

[4] Z. M. Baccar, D. Caballero, N. Zine, N. Jaffrezic-Renault, and A. Errachid, "Development of urease/layered double hydroxides nanohybrid materials for the urea detection: Synthesis, analytical and catalytic characterizations," Sensor Lett., vol. 7, pp. 676-682, Oct. 2009.

[5] M. Temani, Z. M. Baccar, and H. B. Mansour, "Activity of cholesterol oxidase immobilized on layered double hydroxide nanomaterials for biosensor application: Acacia salicina scavenging power of hypercholesterolemia therapy," Microelectron. Eng., vol. 126, pp. 165-168, Aug. 2014.

[6] M. A. Djebbi, M. Braiek, S. Hidouri, P. Namour, N. Jaffrezic-Renault, and A. B. H. Amara, "Novel biohybrids of layered double hydroxide and lactate dehydrogenase enzyme: Synthesis, characterization and catalytic activity studies," J. Mol. Struct., vol. 1105, pp. 381-388, Feb. 2016. [Online]. Available: https://doi.org/10.1016/j.molstruc.2015.10.065

[7] Q. V. Vuong et al., "Fruit-derived phenolic compounds and pancreatic cancer: Perspectives from Australian native fruits," J. Ethnopharmacol., vol. 152, no. 2, pp. 227-242, 2014.

[8] Z. M. Baccar, S. Hidouri, N. El Bari, N. Jaffrezic-Renault, A. Errachid, and N. Zine, "Stable immobilization of anti-beta casein antibody onto layered double hydroxides materials for biosensor applications," Sensor Lett., vol. 7, no. 5, pp. 647-655, 2009.

[9] A. C. Vieira, R. L. Moreira, and A. Dias, "Raman scattering and Fourier transform infrared spectroscopy of $\mathrm{Me}_{6} \mathrm{Al}_{2}(\mathrm{OH})_{16} \mathrm{Cl}_{2} \cdot 4 \mathrm{H}_{2} \mathrm{O}(\mathrm{Me}=$ $\mathrm{Mg}, \mathrm{Ni}, \mathrm{Zn}, \mathrm{Co}$, and $\mathrm{Mn})$ and $\mathrm{Ca}_{2} \mathrm{Al}(\mathrm{OH})_{6} \mathrm{Cl} \cdot 2 \mathrm{H}_{2} \mathrm{O}$ hydrotalcites," J. Phys. Chem. C, vol. 113, no. 30, pp. 13358-13368, 2009.

[10] S. Kannan and C. S. Swamy, "Synthesis and physicochemical characterization of cobalt aluminium hydrotalcite," J. Mater. Sci. Lett., vol. 11, no. 23, pp. 1585-1587, Jan. 1992. [Online]. Available: https://link.springer.com/article/10.1007/BF00740840

[11] J. E. O'Reilly, "Oxidation-reduction potential of the ferro-ferricyanide system in buffer solutions," Biochim. Biophys. Acta-Bioenergetics, vol. 292, no. 3, pp. 509-515, 1973.

[12] R. Villalonga, P. Díez, S. Casado, E. Eguílaz, P. Yáñez-Sedeño, and J. M. Pingarrón, "Electropolymerized network of polyamidoamine dendron-coated gold nanoparticles as novel nanostructured electrode surface for biosensor construction," Analyst, vol. 137, no. 2, pp. 342-348, 2012. 
[13] D. Li et al., "NiCu alloy nanoparticle-loaded carbon nanofibers for phenolic biosensor applications," Sensors, vol. 15, no. 11, pp. 29419-29433, 2015.

[14] I. M. Apetrei, M. L. Rodriguez-Mendez, C. Apetrei, and J. A. de Saja, "Enzyme sensor based on carbon nanotubes/cobalt(II) phthalocyanine and tyrosinase used in pharmaceutical analysis," Sens. Actuators B, Chem., vol. 177, pp. 138-144, Feb. 2013.

[15] D. Shan, C. Mousty, and S. Cosnier, "Subnanomolar cyanide detection at polyphenol oxidase/clay biosensors," Anal. Chem., vol. 76, no. 1, pp. 178-183, 2004.

[16] D. A. Oriero, I. O. Gyan, B. W. Bolshaw, I. F. Cheng, and D. E. Aston, "Electrospun biocatalytic hybrid silica-PVA-tyrosinase fiber mats for electrochemical detection of phenols," Microchemical J., vol. 118, pp. 166-175, 2015.

[17] M. Friedman, C. E. Levin, S.-H. Choi, E. Kozukue, and N. Kozukue, "HPLC analysis of catechins, theaflavins, and alkaloids in commercial teas and green tea dietary supplements: Comparison of water and $80 \%$ ethanol/water extracts," J. Food Sci., vol. 71, no. 6, pp. C328-C337, 2006.

[18] S. Nadifiyine, C. Calas-Blanchard, A. Amine, and J.-L. Marty, "Tyrosinase biosensor used for the determination of catechin derivatives in tea: Correlation with HPLC/DAD method," Food Nutrition Sci., vol. 4, pp. 108-118, Jan. 2013.

[19] M. Cortina-Puig, X. Muñoz-Berbel, C. Calas-Blanchard, and J.-L. Marty, "Diazonium-functionalized tyrosinase-based biosensor for the detection of tea polyphenols," Microchim. Acta, vol. 171, pp. 187-193, Oct. 2010.

[20] B. Wang, J. Zhang, and S. Dong, "Silica sol-gel composite film as an encapsulation matrix for the construction of an amperometric tyrosinase-based biosensor," Biosensors Bioelectron., vol. 15, pp. 397-402, Oct. 2000.

[21] S. Wang, Y. Tan, D. Zhao, and G. Liu, "Amperometric tyrosinase biosensor based on $\mathrm{Fe}_{3} \mathrm{O}_{4}$ nanoparticles-chitosan nanocomposite," Biosensors Bioelectron., vol. 23, pp. 1781-1787, 2008.

[22] J. Zhang, J. Lei, Y. Liu, J. Zhao, and H. Ju, "Highly sensitive amperometric biosensors for phenols based on polyaniline-ionic liquidcarbon nanofiber composite," Biosensors Bioelectron., vol. 24, no. 7, pp. 1858-1863, 2009.

[23] J. Kochana et al., "Tyrosinase-based biosensor for determination of bisphenol A in a flow-batch system," Talanta, vol. 144, pp. 163-170, Nov. 2015.

[24] S. Andreescu and O. A. Sadik, "Correlation of analyte structures with biosensor responses using the detection of phenolic estrogens as a model," Anal. Chem., vol. 76, no. 3, pp. 552-560, 2004.
[25] S. Cosnier, C. Mousty, X. Cui, X. Yang, and S. Dong, "Specific determination of $\mathrm{As}(\mathrm{V})$ by an acid phosphatase-polyphenol oxidase biosensor," Anal. Chem., vol. 78, no. 14, pp. 4985-4989, 2006.

[26] S. Gauthier, J. P. Aimé, T. Bouhacina, A. J. Attias, and B. Desbat, "Study of grafted silane molecules on silica surface with an atomic force microscope," Langmuir, vol. 12, no. 21, pp. 5126-5137, 1996.

[27] H. Lineweaver and D. Burk, "The determination of enzyme dissociation constants," J. Amer. Chem. Soc., vol. 56, no. 3, pp. 658-666, 1934.

[28] H. Xue and Z. Shen, "A highly stable biosensor for phenols prepared by immobilizing polyphenol oxidase into polyaniline-polyacrylonitrile composite matrix," Talanta, vol. 57, no. 2, pp. 289-295, 2002.

[29] E. Dempsey, D. Diamond, and A. Collier, "Development of a biosensor for endocrine disrupting compounds based on tyrosinase entrapped within a poly(thionine) film," Biosensors Bioelectron., vol. 20, pp. 367-377, Sep. 2004.

[30] I. M. Apetrei and C. Apetrei, "The biocomposite screen-printed biosensor based on immobilization of tyrosinase onto the carboxyl functionalised carbon nanotube for assaying tyramine in fish products," J. Food Eng., vol. 149, pp. 1-8, Mar. 2015.

[31] M. S.-P. Lopez, F. Leroux, and C. Mousty, "Amperometric biosensors based on LDH-ALGINATE hybrid nanocomposite for aqueous and non-aqueous phenolic compounds detection," Sens. Actuators B, Chem., vol. 150 , pp. 36-42, Sep. 2010.

[32] D. Tonelli, E. Scavetta, and M. Giorgetti, "Layered-double-hydroxidemodified electrodes: Electroanalytical applications," Anal. Bioanal. Chem., vol. 405, pp. 603-614, Jan. 2013.

[33] H. Notsu, T. Tatsuma, and A. Fujishima, "Tyrosinase-modified borondoped diamond electrodes for the determination of phenol derivatives," J. Electroanal. Chem., vol. 523, pp. 86-92, Apr. 2002.

[34] V. C. Sanz, M. L. Mena, A. González-Cortés, P. Yáñez-Sedeño, and J. M. Pingarrón, "Development of a tyrosinase biosensor based on gold nanoparticles-modified glassy carbon electrodes: Application to the measurement of a bioelectrochemical polyphenols index in wines," Anal. Chim. Acta, vol. 528, no. 1, pp. 1-8, 2005.

[35] R. A. Sheldon, "Enzyme immobilization: The quest for optimum performance," Adv. Synth. Catal., vol. 349, pp. 1289-1307, Jun. 2007.

[36] E. Han, D. Shan, H. Xue, and S. Cosnier, "Hybrid material based on chitosan and layered double hydroxides: Characterization and application to the design of amperometric phenol biosensor," Biomacromolecules, vol. 8, no. 3, pp. 971-975, 2007.

[37] T.-S. Chang, "An updated review of tyrosinase inhibitors," Int. J. Mol. Sci., vol. 10, no. 6, pp. 2440-2475, 2009. 